\title{
CORRESPONDENCE
}

\section{THEY GAVE THEIR LIVES: A TRIBUTE TO THE KNOWN AND UNKNOWN NURSE MARTYRS OF OUR TIME.}

\section{Dear Editor}

After reading the articles on "--Nurse Martyrs of our Time" by Silvia Pera, I was inspired by the selfless devotion to duty and caring for others, that these nurses displayed. The abnormally courageous way they suffered and died in the face of blind, irrational hatred was truly amazing.

Surely it is Christ, who gives this grace and courage to meet the moment. Christ himself suffered blind irrational hatred and suffered as a "lamb to the slaughter", yet he could pray "Father, forgive them for they know not what they do".

se mainly Christian nurses believed that their reward is in heaven and would probably echo what Paul says in Philippians 1 verse 21 "For me to live is Christ and to die is gain".

Christ has told us to be the ambassadors of His Gospel of love and forgiveness. We are to love our enemies and forgive them, as Christ has forgiven us.

As a committed Christian, I believe these nurses are in glory with Jesus Christ, our Lord.

Those of us in South Africa should be prepared to be as committed to the service of our patients wherever we are, and maybe die for our faith in the line of duty.

Yours sincerely

\section{Kathy Newman} Nursing Service Manager Townhill Hospital Pietermaritzburg

\section{IOB INVOLVEMENT AND JOB SATISFACTION OF UTII AFRICAN NURSES COMPARED WITII OTHER PROFESSIONS}

\section{Dear Editor,}

As a professional nurse I read with interest and concern the article on Job Involvement and Job Satisfaction of SA nurses compared with other professionals in the country by Kaplan, Boshoff and Kellerman. As the authors state, the results are disturbing for the nursing profession but, because of the overall $46 \%$ no-response rate, could one argue that the particularly unhappy nurses took the opportunity of filling in the questionnaire to vent their feelings? Did the responding nurses state in which area of nursing they worked? For example, nurses working in community usually have considerably more autonomy than nurses working in the state hospitals.

Yours sincerely

\section{PREVENTIVE SELF-CARE IN TIIREE FREE STATE COMMUNITIES}

\section{Dear Editor,}

It is with interest that I read the research article on preventive self-care in three Free State Communities in the October issue of Curationis. This clearly highlights the real need for an available, accessible and approriate health service.

The Minister of Health's expectations that individuals must take responsibility for their own health is totally unrealistic unless this is backed up with the provision of a health service sensitive to and able to meet the needs of the community it serves. One of many examples of deficiencies in the present health service is the difficulty that even family planning clients have in obtaining a Pap smear. I hope that van Zyl-Schalekamp's research will lead to positive changes in the South African Health Care Delivery System.

Yours sincerely

Mrs. Wendy Lewis
Department of Nursing
University of Natal

\section{BOSHOFF'S RESPONSE}

\section{Dear Editor,}

The issue identified and addressed by the correspondent is highly relevant in social research. It is especially relevant in studies where survey research is the methodology employed. The point about possible bias in the sense of mainly dissatisfied nurses responding in the sludy reported is therefore taken. We could,however, only report what we had found. It should also be pointed out that steps were taken to conceal the identity of the three measuring instruments in the questionnaire to guard against attempts at faking. This is stated in the article.

The second point, i.e. whether we found possible variation in the levels of job sat isfaction and job involvement of nurses according to work situation (and possibly also demographic) variables will be addressed in an article which is currently in preparation.

Taking all present information into account one should probably conclude that at least some nurses are very discontented with their work - at least in comparison with individuals from other professions who responded to the questionnairc.

Yours sincerely 